\title{
BOdY MASS AND LiPID Changes BY HibERNATING REPRODUCTIVE AND NONREPRODUCTIVE BLACK BEARS
}

\author{
HENRY J. HARLOW $\downarrow$ THOMAS LOHUIS $\downarrow$ DEPARTMENT OF ZOOLOGY \& PHYSIOLOGY \\ UNIVERSITY OF WYOMING $\downarrow$ LARAMIE
}
DANIEL B. TINKER $\downarrow$ DEPARTMENT OF GEOSCIENCES AND NATURAL RESOURCE MANAGEMENT $\downarrow$ WESTERN CAROLINA UNIVERSITY $\downarrow$ CULlOWHEE $\downarrow$ NC RONALD G. GROGAN $\downarrow$ WYOMING GAME AND FISH DEPARTMENT LARAMIE

\section{THOMAS D.I. BECK $\downarrow$ COLORADO DIVISION OF WILDLIFE $\downarrow$ FORT COLLINS}

\begin{abstract}
$\downarrow \quad$ ABSTRACT
Black bears have delayed implantation with fetal development and lactation energy demands during a period of maternal hibernation and starvation. Pregnant females in a state of diapause had about $23 \%$ greater fat depots than nonreproductive females going into hibernation. Fat provided $92 \%$ of the total energy for lactation and gestation. Rates of fat loss were $27 \%$ and protein loss $58 \%$ higher for reproductive females compared to non-reproductive females. The cost of winter reproduction to include gestation and lactation was $1432 \mathrm{kj} /$ day to produce two cubs. While reproduction required elevated protein breakdown, the overall loss was relatively small, perhaps due to a short gestation period and urea recycling.
\end{abstract}

\section{$\downarrow \quad$ INTRODUCTION}

Black bears are unique among hibernators in that they mate in June and July, implant in November/December (Kordek and Lindzey 1980) with parturition in January (Alt, 1983). Cubs then nurse in the den 10-12 weeks until late March or early April (Alt, 1982). As such, black bears express their highest reproductive energy demands while in a state of hibernation and starvation. Little is known about how much fat is accumulated in the fall for hibernation by free-ranging black bears, the amount of energy required to sustain gestation and lactation over the winter and the proportion of maternal protein to fat required to successfully produce cubs. The knowledge of nutrient requirements for hibernating reproductive and non-reproductive bears is important to understanding winter survival of these animals and to formulate management decisions based upon food availability and spring emergence conditions.

The purpose of the present study was to determine fall body fat of reproductive and nonreproductive bears and calculate the additional fat, protein and energy demands for cub production by hibernating females. 


\section{METHODS}

Three areas containing bears were included in this study: 1) the Uncompahgre Plateau, Colorado, 2) Middle Park, Colorado and 3) Snowy Range Mountains, Wyoming.

Bioelectrical Impedance Analysis (BIA) measures the resistance of a weak alternating electrical current $(800 \mathrm{uA}$ at $50 \mathrm{KHz})$ made to pass through the body of an animal. The flow of current is directly related to body water content. Because lipids have lower water content than fat-free tissue, there is a direct correlation between resistance and the amount of body fat. Body water was calculated from resistance values (RJL Systems model 101-Q Impedance meter), body mass $(\mathrm{kg})$ and snout to vent length $(\mathrm{cm})$ using formulas in Table 1 from Farley and Robbins (1994). Body water was then used to calculate fat from the formulas expressed in Figure 1 also from Farley and Robbins (1994).

Body mass and fat were measured on 4 groups of bears from the 3 study areas during early and late winter. Five reproductive female bears and one non-reproductive female were monitored starting in November 1994 from the Uncompahgre Plateau. Four non-reproductive female bears were monitored in the Snowy Range Mountains from southeastern Wyoming starting in February, 1996. Six nonreproductive and 2 reproductive female bears were monitored in Middle Park, Colorado starting in November 1997 and 5 reproductive females and one non reproductive female were measured from the same area in 1998.

Bears were anesthetized using Telazol $(7 \mathrm{mg} / \mathrm{kg})$ or ketamine hydrochloride/xylaxine hydrochloride $(200 \mathrm{mg} / \mathrm{kg}$ ketamine and $50 \mathrm{mg} / \mathrm{ml}$ xylaxine) administered with a jab stick or Palmer dart gun in the den. The bears were removed from the den, weighed using a model (Dyna Link 1200) digital load scale (200 gm accuracy), and placed upon an inflatable pad and plastic tarp for appropriate positioning for BIA (Farley and Robbins, 1994). The BIA instrument consists of a hand-held impedance meter with two pairs of leads. One pair was attached to 20-gauge vacutainer needles inserted into the fat deposits $2 \mathrm{~cm}$ on either side of the base of the tail. The other pair was attached, via small clips, to the bear's upper lip just above the canines. Great care was taken to maintain consistency of bears positioning and lead placement, and all measurements of resistance and body mass were taken at least twice to insure precision.
Assuming that the hydration of lean tissue remained constant over the sampling period, (hematocrits remained constant) protein was taken to comprise $22.3 \%$ of lean body mass (Farley and Robbins, 1994). Using constants of 39.3 and 23.6 $\mathrm{kJ} / \mathrm{g}$ for the energy content of fat and muscle protein (Blaxter, 1989), we converted body composition changes into units of energy. Fall body mass and fat as well as rates of fat and protein use by reproductive and non-reproductive bears was compared using an ANOVA test for significance.

\section{RESULTS}

While reproductive females were heavier and had significantly greater $(23 \%)$ fat stores than non-reproductive females, lean body mass was not significantly different (Table 1). The mean rate of body mass loss of reproductive females was $42 \%$ greater ( $196.5 \mathrm{~g} /$ day Vs. $115.6 \mathrm{~g} /$ day) and the rate of fat loss was $27 \%$ greater $(115.9 \mathrm{~g} /$ day vs. $84.7 \mathrm{~g} /$ day $)$ than for non-reproductive females (Figure 1). Daily total energy expenditure of reproductive females was significantly higher (4946 kJ/day Vs $3514 \mathrm{~kJ} /$ day) than for non-reproductive females (Table 2). Fat provided about $88 \%$ of the total energy expenditure for reproductive bears during the winter (Table 2). Even though protein was a minor energy substrate compared to fat, over twice the amount of protein $(15.5 \mathrm{~g} /$ day Vs. $6.5 \mathrm{~g} /$ day) was used by reproductive bears compared to non-reproductive bears.

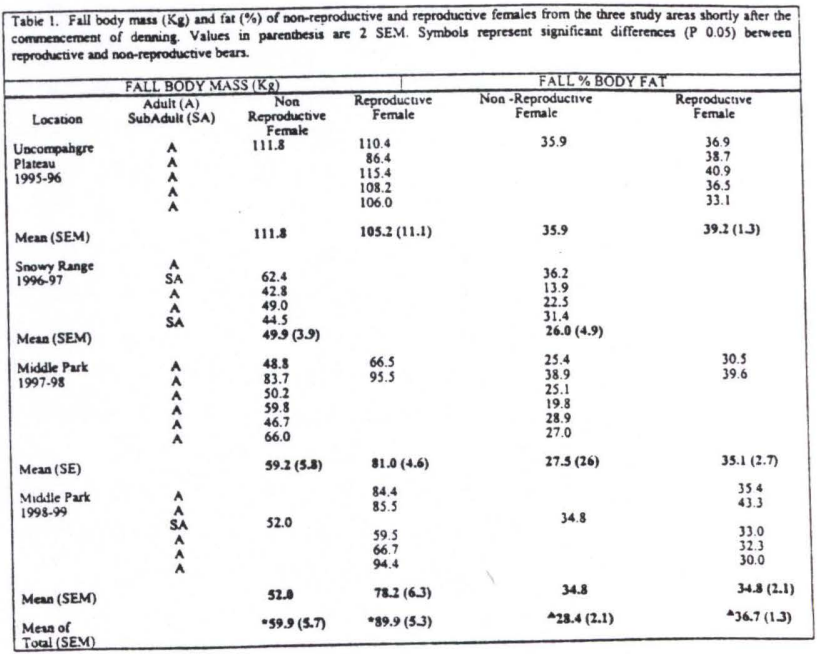




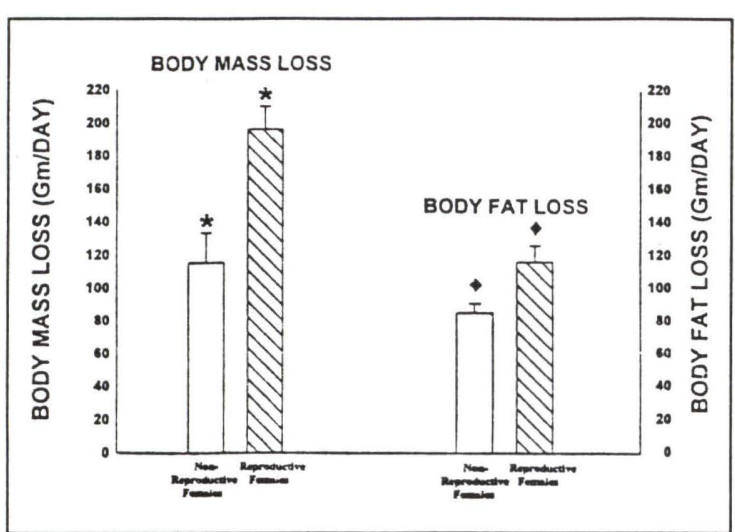

Figure 1. Body mass and body fat loss (gm/day) by 12 reproductive and 12 non-reproductive female black bears from the three study areas. Symbols depict a significant difference $(0.05)$ between reproductive and non-reproductive groups. Vertical bars represent 2 SEM.

There was no difference in weight and fat loss between subadult and adult non-reproductive females. Non-reproductive females were the same body mass and had the same body fat content in the Snowy Range and the Middle park study areas. Even though reproductive females in the Uncompahgre Plateau population were significantly larger than those from the Middle park population, they did not have greater levels of fat (Table 1).

\begin{tabular}{|c|c|c|c|c|c|}
\hline Condition & $\begin{array}{l}\text { Fat Loss } \\
\text { (a'day) }\end{array}$ & $\begin{array}{l}\text { Protein Loss } \\
\text { (y/day) }\end{array}$ & $\begin{array}{l}\text { Eoerzy Expendiure } \\
\text { From Fat } \\
\text { (ld/day) }\end{array}$ & $\begin{array}{l}\text { Energy Expenditure } \\
\text { From Protein } \\
\text { (ll/day) }\end{array}$ & \begin{tabular}{|l}
$\begin{array}{l}\text { Toual Energy } \\
\text { Expenditure } \\
\text { (bl/(day) }\end{array}$ \\
\end{tabular} \\
\hline $\begin{array}{l}\text { Lactanang } \\
\text { Femmeles }\end{array}$ & $\cdot 115.8(10.5)$ & $\cdot 15.4(2.2)$ & $\cdot 4570(4.3)$ & $\cdot 374(53)$ & ${ }^{-4946(397)}$ \\
\hline $\begin{array}{l}\text { Non- Lectating } \\
\text { Females }\end{array}$ & ${ }^{8} 8.7(17.0)$ & $\cdot 6.5(2.7)$ & • 3354 (691) & $\cdot 160(63)$ & ${ }^{-3514(678)}$ \\
\hline
\end{tabular}

\section{$\uparrow \quad$ DISCUSSION}

Bears become hyperphagic in the fall and accumulate body fat. They then stop eating and enter a physiological state conducive for fat metabolism and protein sparing (Nelson, 1980). During this period they can enter a den and allow their body temperature to fall several degrees for the remaining winter (Nelson et al., 1973). Females that were bred during the summer harbor the fertilized blastocyst in a state of diopause until mid winter implantation followed by a relatively short (about 32 days) in utero gestation and then by a protracted lactation through the winter denning period (Alt, 1982; Kordek and Lindzey, 1980). Most mammals do not simultaneously undergo starvation and reproduction. In order to be adapted to such conditions, bears must have ample stores of both fat as well as protein.

Fall Body Mass and Fat Stores By NonReproductive and Reproductive Bears.
Sampson and Huot (1995) measured body mass of free ranging female black bears in a reproductive and non-reproductive state in the Great Lakes-St. Lawrence River Region during the early winter just after denning. Bears in a reproductive state (which later produced 2 to 3 cubs) weighed significantly more $(85-95 \mathrm{~kg})$ than the nonreproductive females $(53 \mathrm{~kg})$. The additional weight was thought to represent energy stores which were related to successful cub production (Sampson and Huot, 1995). These weights are remarkably similar to the values obtained in the present study for reproductive $(89.9 \mathrm{~kg})$ and non-reproductive $(53 \mathrm{~kg})$ females under natural field conditions in the Colorado, and Wyoming Rocky Mountains. Unlike the study by Sampson and Huot (1995), we were able to show that this mass difference was primarily due to a $23 \%$ higher storage of fat. Interestingly, the fall hyperphagic period for bears is characterized by a reproductive state of blastocyst arrest with very little additional energy demands on the pregnant female. Therefore, during this time, there must be alterations in the hypothalamic control of appetite and body fat set point by pregnant females that are not energy driven to make them eat more and place on additional reserves to accommodate later demands. It is not known what neural or hormonal signals cause these changes in bears, however, we have previously demonstrated that fall levels of progesterone are elevated in female bears believed to be in a state of diapause (Harlow et al. 1990). This and/or other hormonal messengers such as leptin, neural peptide $\mathrm{Y}$ or cholystokinin may orchestrate an altered food intake and energy storage in the fall by pregnant females in the absence of direct energy demands.

\section{Rates of Winter Body Mass and Fat Loss by Non- Reproductive Bears}

Studies on captive non-reproductive bears show overwinter body mass losses of between 70-310 g/day (Craighead et al., 1976; Maxwell et al., 1988). This great variability among studies may be a result of differing energy demands associated with captivity, amount of handling and type of artificial dens used. On the other hand, our values $(115.6 \mathrm{~g} /$ day $)$ were closer to the $70-100 \mathrm{~g} /$ day mass loss previously reported by Craighead et al (1976) and by Tietje and Ruff (1980) both studies reporting on a very small sample size $(n=2)$ of nonreproductive females in the wild. In a more exhaustive study on free ranging bears, Sampson and Huot (1995) monitored 6 non-reproductive female bears twice during the winter. Their value for body mass loss by non-reproductive females of 100 
gm/day was very close to that reported here $(115.6$ gm/day).

The only studies on daily winter fat loss of black bears have been conducted on captive bears. Maxwell et al. (1998) demonstrated that a nonreproductive bear in an artificial den lost 55 to $65 \mathrm{~g}$ fat /day which was in the range, but somewhat lower than the $85 \mathrm{~g}$ fat/day reported in this paper on 12 nonreproductive female bears while in their natural dens.

\section{Body Mass, Fat and Protein Loss By Reproductive Females: Cost of Gestation and Lactation.}

Few data have been published describing the loss of mass in wild black bears in relation to gestation and lactation during the winter. Sampson and Huot (1995) reported body mass loss estimated to be about $230 \mathrm{~g} /$ day for reproductive female black bears in a state of gestation and lactation while Oftedal et al. (1993) showed a loss of about 270 $\mathrm{g} /$ day for the first month of lactation for two cubs. Our values of $196 \mathrm{~g} /$ day loss to maintain two cubs were closer to that of Sampson and Huot (1995) for combined gestation and lactation over the winter. This represents an approximate $41 \%$ increase in mass loss due to reproduction which is similar to the $45 \%$ reported by Farley and Robbins (1995) on captive bears.

In our study on hibernating bears under natural field conditions, the difference in combined fat and protein loss between reproductive and nonreproductive female bears was $40 \mathrm{~g} /$ day or an equivalence of $1432 \mathrm{kj} /$ day per litter of 2 cubs (Table 2 ). Indeed, we found that reproductive females had a $1216 \mathrm{~kJ} /$ day higher expenditure of fat while only 214 $\mathrm{kJ} /$ day higher expenditure of protein compared to non-reproductive females over the winter test period (Table 2). The present study suggests a low use of protein by reproductive hibernating bears. Lactating females appeared to greatly conserve protein with a fat to protein ratio of about six to one with only $7.6 \%$ protein loss over the winter. Interestingly, even though this additional protein may be providing water and nitrogen required for cub growth, it represents a relatively small amount of protein loss by the mother. For example, humans during inactivity, loose protein at a rate of $0.4 \% /$ day (Berg et al., 1997) which would extrapolate to about $48 \%$ protein loss over a similar 120 day period. Interestingly, it has been proposed by Oftedal et al (1993) that lactating females ingest the urine and feces of the cubs thereby recovering about as much water and about half the nitrogen she looses in milk which could augment other protein conserving processes such as recycling urea (Nelson et al 1973). Therefore, mass loss is primarily due to fat loss and not protein during winter reproduction (Maxwell et al., 1988; Tinker, Harlow and Beck, 1998)

Knowledge of energy requirements for winter reproductive costs is important to understanding winter survival of black bears and to formulate management decisions based upon spring emergence condition. Cub production, sex ratio and survival are influenced by maternal condition and local food availability to black bears (Eiler et al., 1989; Kolenosky, 1990; Stringham, 1990). Regional differences in energy requirements for reproduction could be caused by local variation in denning duration and food availability (Sampson and Huot, 1995).

\section{Literature CiTED}

Alt G.L. 1983. Timing of parturition of black bears (Ursus americanus) in northern Pennsylvania. J. Mammal. 64: 305-307.

Alt, G.L. 1982. Reproductive biology of Pennsylvania's black bear. Pennsylvania Game News 53: 9-15.

Berg, H.E., L Larsson and P.A. Tesch. 1997. Lower limb skeletal muscle function after $6 \mathrm{wk}$ of bed rest. J. Appl. Physiol. 82: 182-188.

Blaxter, K.L. 1989. Energy metabolism in animals and man. Cambridge University Press. Cambridge.

Craighead, J.J., J.R. Varney, F.C. Craighead Jr. and J.S. Sumner. 1976. Telemetry experiments with a hibernating black bear. International Conference on Bear Research and Mgmt. 53: 357-369.

Eiler, J.H., W.G.Wathen and M.R. Pelton. 1989. Reproduction in black bears in the southern Appalachian mountains. J of Wildl. Mgmt. 53: 353-360.

Farley, S.D. and C.T. Robbins. 1994. Development of two methods to estimate body composition of bears. Can. J. Zool. 72:220226. 
Farley, S.D. and C.T. Robbins. 1995. Lactation, hibernation, and mass dynamics of American black bears and grizzly bears. Can. J. Zool. 73: 2216-2222.

Harlow, H.J., T.D.I. Beck, L.M. Walters and S.S. Greenhouse. 1990. Seasonal serum glucose, progesterone and cortisol levels of black bears (Ursus americanus). Can. J. Zool. 68: 183-187.

Kolenosky, G.G. 1990. Reproductive biology of black bears in east-central Ontario. International conference on Bear Research and Management. 8: 385-392.

Kordek, W.S. and J.S. Lindzey. 1980. Preliminary analysis of female reproductive tracts from Pennsylvania black bears. International Conference on Bear Research and Management. 4: 159-161.

Maxwell, R.K., J. Thorkelson, L. Rogers and R.B. Brander. 1988. The field energetics of winter-dormant black bears (Ursus americanus) in northern Minnesota. Can. J. Zool. 66: 2095-2103.

Nelson, R.A., H.W. Wahner, J.D. Jones, R.D. Ellefson and P.E. Zollman. 1973. Metabolism of bears before, during, and after winter sleep. Am. J. Physiol. 224: 491496.
Nelson, R.A. 1980. Protein and fat metabolism in hibernating bears. Fed. Proc. 39: 2955-2958.

Oftedal, O.T., G.L. Alt, E.M. Widdowson and M.R. Jakubasz. 1993. Nutrition and growth of suckling black bears (Ursus americanus) during their mother's winter fast. British J. of Nutrition 70: 59-79.

Sampson, C. and J. Huot. 1995. Reproductive biology of female black bears in relation to body mass in early winter. J. Mammal. 76: 68-77.

Stringham, S.F. 1990. Black bear reproduction rate relative to body weight in hunted populations. International Conference on Bear Research and Management. 8:425-432.

Tietje, W.D. and R.L. Ruff. 1980. Denning behavior of black bears in boreal forests of Alberta. J. Wildl. Manage. 44: 858-870.

Tinker, D.B., H.J. Harlow and T.D.I. Beck. 1998. Protein use and muscle-fiber changes in free-ranging, hibernating black bears. Phys. Zool. 71: 414-424. 